\title{
38. RELATIONSHIPS BETWEEN PHYSICAL PROPERTIES AND MICROFOSSIL CONTENT AND PRESERVATION IN CALCAREOUS SEDIMENTS OF THE ONTONG JAVA PLATEAU ${ }^{1}$
}

\author{
Janice C. Marsters, ${ }^{2}$ Johanna M. Resig, ${ }^{2}$ and James A. Wilcoxon ${ }^{3}$
}

\begin{abstract}
Samples obtained in Hole 803D for shipboard determination of index properties were analyzed to determine their microfossil constituents. The resulting data are compared to shipboard-measured physical properties data to assess the relationships between small-scale fluctuations in physical properties and microfossil content and preservation. The establishment of relationships involving index properties of these highly calcareous sediments is difficult because of the role of intraparticle porosity. Relationships were observed between calculated interparticle porosity and microfossil content. Impedance, calculated using bulk density based on interparticle porosity, exhibits an increase with increasing grain size. Variations in the coarse fraction constituents appear to exert more control over physical properties than variations in the fine-fraction constituents, although the fine fraction make up greater than $85 \%$ of the samples by weight.
\end{abstract}

\section{INTRODUCTION}

Previous studies have suggested a link between the measured physical properties of calcareous sediments and microfossil content and preservation. Johnson et al. (1977) found that the mean grain size of carbonates decreases at deeper depositional sites on the periphery of the Ontong Java Plateau, primarily because of the increased dissolution of foraminifers at greater water depths. The deeper water sediments have lower sound velocities and less shear strength. Mayer (1979) studied eastern equatorial Pacific sediments and found that low carbonate contents corresponded to low densities, which he attributed to the lower density of silica, which made up a more significant portion of the sediments with lower carbonate contents.

Hole 803D, drilled on the Ontong Java Plateau during Leg 130 of the Ocean Drilling Program (ODP), is located in $3410 \mathrm{~m}$ water depth. Figure 1 shows downhole profiles of porosity and compressional wave velocity for the upper $300 \mathrm{~m}$ of Hole 803D. These profiles show general trends of decreasing porosity and slightly increasing velocity with increasing depth. However, imprinted on these trends are a number of small-scale fluctuations, with depth frequencies on the order of meters or tens of meters.

This study was undertaken to determine if these downhole fluctuations in physical properties are related to variations in microfossil content and preservation. The samples obtained for the shipboard determination of index properties were retained for shore-based determination of their microfossil constituents. The depth intervals of these samples also corresponded to those of the velocity measurements. We anticipated that the use of the same samples for the analyses of both microfossil and physical properties parameters would provide a direct link between sediment composition and measured physical and acoustical properties.

\section{PROCEDURES}

The velocity and index properties data used in this study were obtained as part of the shipboard physical properties program. Compressional wave velocity was measured using a Dalhousie University/Bedford Institute of Oceanography Digital Sound Velocimeter

\footnotetext{
${ }^{1}$ Berger, W.H., Kroenke, L.W., Mayer, L.A., et al., 1993. Proc, ODP, Sci, Results. 130: College Station, TX (Ocean Drilling Program).

${ }^{2}$ Department of Geology and Geophysics, School of Ocean and Earth Science and Technology, University of Hawaii, 2525 Correa Road, Honolulu, HI 96822, U.S.A.

${ }^{3} 333$ Aoloa Street, \#335, Kailua, HI 96734 , U.S.A.
}

(DSV; Mayer et al., 1987). One or two velocity measurements were performed per 1.5-m section of core. Velocity calculations were based on the accurate measurement of the flight time of an impulsive acoustic signal traveling between a pair of piezoelectric transducers inserted in the split sediment cores. The signal used was a 2 -ms square wave; the transducers have resonances at about 250 and $750 \mathrm{kHz}$. A dedicated microcomputer controlled all functions of the velocimeter. The transmitted and received signals were digitized by a Nicolet 320 digital oscilloscope and transferred to the microcomputer for processing. The DSV software selected the first arrival and calculated sediment velocity. Thermistors in the transducer probes monitored temperatures while measurements were being performed. The velocity data are corrected to a constant laboratory temperature. Further details of the equipment and methods are provided in the Initial Reports volume (Kroenke, Berger, Janecek, et al., 1991, "Explanatory Notes" chapter, pp. 15-43).

Velocities were measured along the vertical (perpendicular to bedding) and horizontal (parallel to bedding) directions. In general, the two velocity values are very close for the soft oozes of this study; an average of the two values is used here.

Index properties samples were placed in preweighed aluminum containers, and the weights determined to a precision of $\pm 0.01 \mathrm{~g}$ using a motion-compensating Scitech electronic balance. The samples were dried in a $110^{\circ} \mathrm{C}$ oven for $24 \mathrm{hr}$, cooled in a desiccator, and then weighed again to obtain their dry weights. Volumes of the samples were determined to an approximate precision of $10^{-4} \mathrm{~cm}^{3}$ using a Quantachrome helium-displacement pycnometer. Further details of the procedures used can be found in the Initial Reports volume (Kroenke, Berger, Janecek, et al., 1991, pp. 15-43). Details on the methods used for the calculation of index properties, which follow the methods of Boyce (1976), can also be found in the Initial Reports volume (Kroenke, Berger, Janecek, et al., 1991, pp. 15-43). Porosity is calculated as the ratio of the volume of voids to the total sample volume, and bulk density is the ratio of the total sample mass to total sample volume. Index properties have been corrected for salt content according to the equations of Noorany (1984).

Because the intent of this study is to examine the relationship between small-scale fluctuations in physical properties and microfossil content, we have corrected for the depth trend in the physical properties parameters that are affected by compaction, such as porosity, bulk density, and velocity. Second-order polynomial curve fits were applied to each set of property vs. depth data. For example, porosity values decrease from $67.9 \%$ near the seafloor to $53.8 \%$ at 270 mbsf. The equation of the second-order polynomial curve fit 

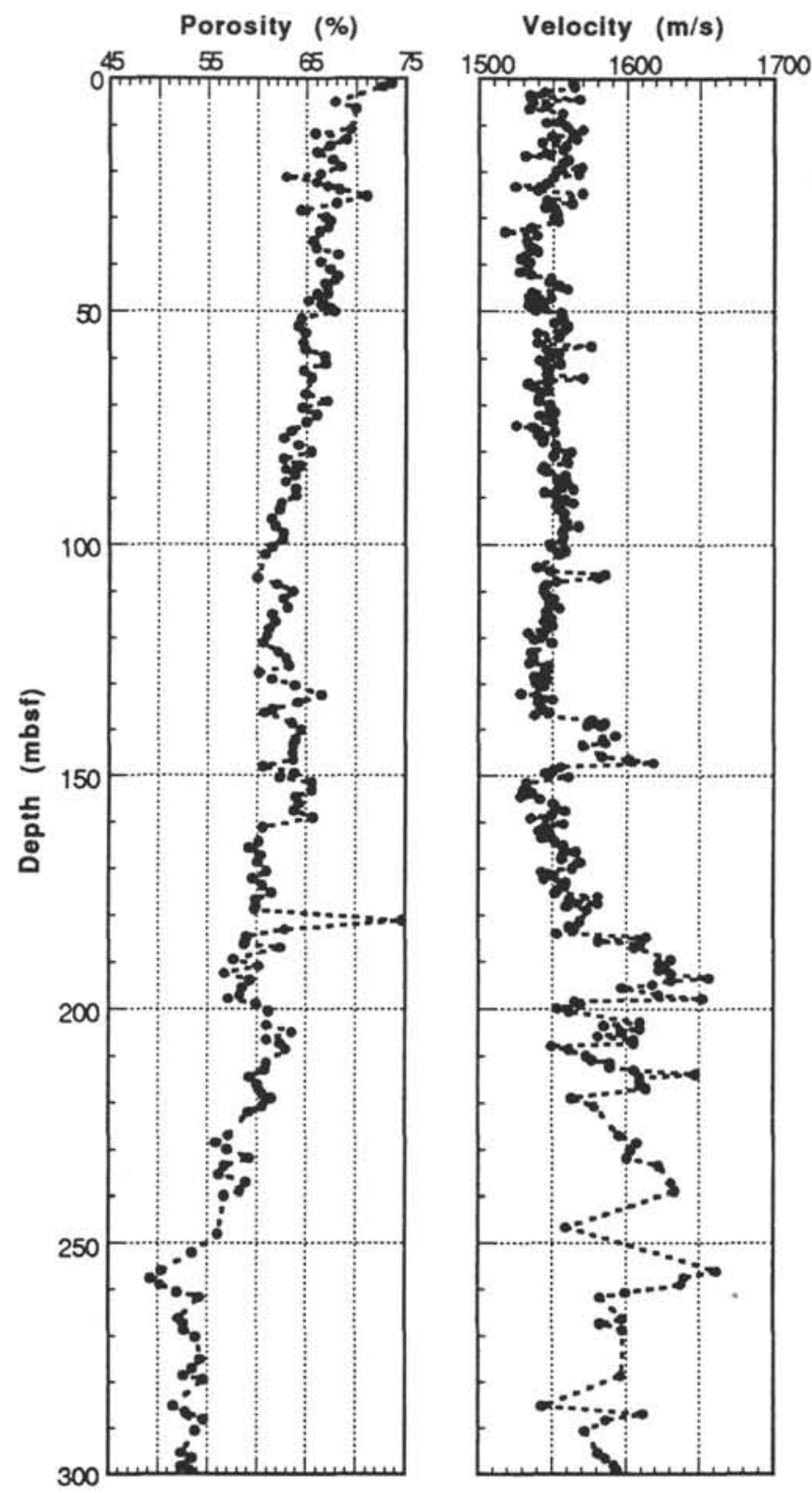

Figure 1. Downhole profiles of porosity and compressional wave velocity for the upper $300 \mathrm{~m}$ of Hole 803D.

representing the porosity data is used to determine the value on the fit curve for each sample depth (e.g., $55.8 \%$ at $270 \mathrm{mbsf}$ ). The porosity at the shallowest sample depth is assumed to represent the "uncompacted" value, and the shipboard data is corrected by the difference between this uncompacted value and the curve fit value for each sample depth. For example, the corrected porosity $(66.8 \%)$ at 270 mbsf equals the measured porosity $(53.8 \%)$ plus the difference between the fit porosity $(55.8 \%)$ and the "uncompacted" value $(67.9 \%)$. This procedure assumes that the compaction of the sediment column can be approximated by the polynomial curve applied. This correction is probably an oversimplification, as some zones exhibit different consolidation behavior (Marsters and Manghnani, this volume).

The samples used in the shipboard index properties determinations were retained for the shore-based microfossil analyses. This study was necessarily restricted to the sediment that could be readily disaggregated (the upper $270 \mathrm{~m}$ of this core). The dry samples were weighed, soaked in water, and then wet sieved through a screen with $63-\mu \mathrm{m}$ openings to isolate the sand fraction. The combined silt and clay fraction was washed into a bucket. After drying, the weight of the sand fraction was recorded to enable computation of the weight percent sand and combined silt and clay.

The dry sand fraction was split by microsplitter to about $1 / 128$ to $1 / 256$ of its original size, and the particles, which numbered about 1000 , were identified and counted. Microfossils $\geq 50 \%$ complete were counted as whole specimens. Principal components of the sand fraction were planktonic foraminifers, fragments of planktonic foraminifers, and radiolarians, which fluctuate in their relative frequency (Table 1). Both an increase in the frequency of radiolarians and/or an increase in the frequency of foraminifer fragments and benthic foraminifers are recognized as a sign of dissolution of carbonate in the sand fraction.

Light microscope slides were prepared for the study of the silt and clay fraction. Approximately $1 / 2$ gram of silt and clay was stirred into a $10-\mathrm{ml}$ beaker of water. A few drops of the resultant mixture were removed with a pipette, spread evenly on a slide, and allowed to dry on a hot plate. A cover glass was affixed to the slide with Caedax mounting medium, and the slide was then reheated on the hot plate for $1 \mathrm{~min}$ to harden the medium, making the mount permanent. This method provided a fairly even distribution of the constituents.

Estimates of the percent frequency of the fine fraction components were made from scanning most of the slide at $600 \times$ (Table 2). Calcareous nannofossils are the main constituent of the samples. A considerable amount of unidentified calcareous material is present and associated with the nannofossils in every sample. Microforaminifers were observed in most samples. Diatoms and radiolarians and related fragments are relatively common in some samples. Overall, very little organic carbon or unidentified minerals are present in the silt and clay fraction.

Preservation of the nannofossils is indicated as moderate if some of the discoasters were coated with secondary calcitic growth. Overgrowth did not appear to affect the coccoliths. Dissolution appeared to be insignificant in the fine fraction.

Samples of the fine fraction were also checked for age based on the calcareous nannofossils. From this examination, it was concluded that reworked sediment was not a factor in the samples studied.

\section{RESULTS}

Grain size values vs. depth for the samples analyzed are shown in Figure $2 \mathrm{~A}$. The fine fraction $(<63 \mu \mathrm{m})$ makes up $>90 \mathrm{wt} \%$ of most of the samples. The samples from the upper $50 \mathrm{~m}$, however, contain $10 \%-30 \%$ coarse particles $(>63 \mu \mathrm{m})$.

The components of counted coarse and fine particles are also shown in Figure 2B. Four components total $>98 \%$ of the total coarse particles; the other components of the coarse fraction are not plotted. "Planktonic foraminifers" refers to specimens with tests estimated to be $\geq 50 \%$ complete. "Foraminifer fragments" refers to both planktonic and benthic foraminifers with tests estimated to be $<50 \%$ complete. The planktonic fragments were estimated to comprise $98 \%$ of the total fragments.

Numerous fluctuations were present in the relative percentages of the major constituents of the coarse fraction. However, some general trends were observed. Radiolarian content increased downcore; the samples near the surface usually contained $<5 \%$ radiolarians. The radiolarian content of the majority of samples below $150 \mathrm{mbsf}$ was $>50 \%$. The percentage of foraminifer fragments generally decreased downhole, from values $>80 \%$ near the surface to $<50 \%$ below 120 mbsf. The general trend of decreasing foraminifer fragments and increasing radiolarian content with increasing depth implies postburial dissolution of the calcareous fragments and thus an increase in the radiolarian/calcareous fragment ratio. Fragments reach the seafloor already having undergone significant calcite dissolution and are generally the particles most susceptible to complete dissolution following burial. Planktonic foraminifers exhibit no general depth 
Table 1. Number of sand-sized $(>63 \mu \mathrm{m})$ particles and individual constituents of sand fraction in calcareous sediments of the Ontong Java Plateau.

\begin{tabular}{|c|c|c|c|c|c|c|c|c|}
\hline $\begin{array}{l}\text { Depth } \\
\text { (mbsf) }\end{array}$ & $\begin{array}{l}\text { Coarse fraction } \\
\text { (\% total sample } \\
\text { weight) }\end{array}$ & $\begin{array}{l}\text { Planktonic } \\
\text { foraminifers } \\
\text { (\% coarse) }\end{array}$ & $\begin{array}{c}\text { Benthic } \\
\text { foraminifers } \\
\text { ( } \% \text { coarse) }\end{array}$ & $\begin{array}{l}\text { Foraminifer } \\
\text { fragments } \\
\text { (\% coarse) }\end{array}$ & $\begin{array}{l}\text { Radiolarians } \\
\text { (\% coarse) }\end{array}$ & $\begin{array}{l}\text { Diatoms } \\
\text { (\% coarse) }\end{array}$ & $\begin{array}{c}\text { Other } \\
\text { (\% coarse) }\end{array}$ & $\begin{array}{l}\text { Minerals } \\
\text { (\% coarse) }\end{array}$ \\
\hline 5.07 & 11.31 & 9.5 & 1.7 & 85.1 & 3.3 & 0 & 0 & 0.4 \\
\hline 6.49 & 13.42 & 15.1 & 1.6 & 79.8 & 3.5 & 0 & 0 & 0 \\
\hline 9.46 & 15.81 & 3.2 & 2.2 & 91.4 & 2.8 & 0 & 0.2 & 0.2 \\
\hline 20.59 & 20.87 & 17.8 & 0.9 & 79.6 & 1.5 & 0 & 0.1 & 0 \\
\hline 24.10 & 21.64 & 32.5 & 0.7 & 65.8 & 1.0 & 0 & 0 & 0.1 \\
\hline 25.51 & 30.42 & 38.7 & 0.2 & 59.3 & 1.9 & 0 & 0 & 0 \\
\hline 30.79 & 22.87 & 15.8 & 0.5 & 81.6 & 2.0 & 0 & 0.1 & 0 \\
\hline 33.11 & 20.87 & 2.0 & 0.9 & 88.7 & 8.0 & 0 & 0.3 & 0 \\
\hline 38.10 & 16.43 & 16.8 & 1.1 & 81.6 & 0.3 & 0 & 0.2 & 0 \\
\hline 39.60 & 9.58 & 7.1 & 1.2 & 78.3 & 13.2 & 0 & 0.1 & 0.1 \\
\hline 43.36 & 10.76 & 17.5 & 1.1 & 77.7 & 3.6 & 0 & 0 & 0.1 \\
\hline 44.89 & 15.31 & 11.5 & 0.7 & 80.0 & 7.6 & 0 & 0.1 & 0 \\
\hline 46.35 & 7.80 & 8.8 & 1.8 & 82.6 & 6.7 & 0 & 0 & 0.1 \\
\hline 46.46 & 10.55 & 8.8 & 1.3 & 81.9 & 7.6 & 0 & 0.3 & 0 \\
\hline 48.70 & 6.89 & 4.2 & 1.0 & 88.4 & 6.2 & 0 & 0.3 & 0 \\
\hline 51.70 & 8.84 & 5.5 & 1.0 & 76.4 & 16.9 & 0 & 0 & 0.3 \\
\hline 62.70 & 8.45 & 8.5 & 0.6 & 68.7 & 22.0 & 0 & 0.2 & 0 \\
\hline $73-68$ & 5.24 & 6.5 & 1.1 & 70.8 & 21.1 & 0.3 & 0 & 0.2 \\
\hline 75.60 & 5.11 & 19.1 & 1.1 & 57.3 & 22.3 & 0.1 & 0 & 0.1 \\
\hline 77.17 & 3.86 & 11.0 & 1.4 & 69.3 & 18.0 & 0.1 & 0.3 & 0 \\
\hline 83.19 & 7.62 & 13.8 & 0.5 & 73.7 & 11.7 & 0.1 & 0.1 & 0.1 \\
\hline 83.95 & 5.29 & 7.8 & 1.1 & 70.7 & 20.0 & 0 & 0.1 & 0.2 \\
\hline 88.18 & 8.73 & 25.0 & 0.7 & 53.1 & 21.0 & 0.1 & 0 & 0.1 \\
\hline $89-69$ & 6.75 & 11.1 & 0.9 & 61.6 & 25.5 & 0.9 & 0 & 0.1 \\
\hline 93.46 & 5.41 & 6.9 & 1.2 & 65.1 & 25.7 & 0.5 & 0.2 & 0.4 \\
\hline 94.70 & 4.24 & 4.9 & 0.6 & 58.0 & 35.8 & 0.4 & 0 & 0.4 \\
\hline 100.70 & 3.82 & 12.9 & 1.3 & 58.0 & 27.5 & 0.1 & 0 & 0.1 \\
\hline 107.17 & 2.40 & 18.8 & 0.6 & 41.8 & 38.6 & 0 & 0 & 0.2 \\
\hline 111.68 & 6.14 & 13.7 & 1.0 & 73.9 & 11.4 & 0 & 0 & 0 \\
\hline 115.14 & 4.83 & 12.2 & 0.4 & 45.5 & 41.2 & 0.1 & 0 & 0.6 \\
\hline 118.51 & 2.86 & 17.6 & 0.8 & 39.7 & 41.7 & 0 & 0.1 & 0.1 \\
\hline 119.58 & 3.24 & 15.2 & 0.6 & 38.6 & 45.1 & 0.1 & 0 & 0.4 \\
\hline 123.20 & 3.22 & 25.9 & 1.5 & 39.4 & 32.6 & 0 & 0 & 0.6 \\
\hline 124.68 & 4.39 & 29.7 & 0.3 & 41.8 & 28.2 & 0 & 0 & 0 . \\
\hline 127.69 & 3.45 & 16.9 & 1.2 & 46.0 & 35.5 & 0 & 0 & 0.4 \\
\hline 129.13 & 6.60 & 38.5 & 0.4 & 32.5 & 27.4 & 0.8 & 0 & 0.4 \\
\hline 135.70 & 4.72 & 12.7 & 0.8 & 47.3 & 38.4 & 0.8 & 0 & 0 \\
\hline 138.68 & 12.87 & 68.1 & 0.1 & 16.9 & 14.8 & 0 & 0.1 & 0 \\
\hline 140.19 & 14.31 & 60.9 & 0.3 & 22.7 & 16.1 & 0 & 0 & 0 \\
\hline 145.17 & 14.07 & 55.8 & 0.1 & 19.7 & 24.3 & 0.1 & 0 & 0 \\
\hline 148.20 & 8.28 & 25.5 & 0.3 & 37.5 & 36.1 & 0.3 & 0.2 & 0 \\
\hline 149.59 & 5.65 & 13.2 & 0.6 & 28.7 & 57.5 & 0 & 0 & 0 \\
\hline 154.69 & 3.60 & 1.7 & 1.6 & 23.8 & 72.8 & 0 & 0.1 & 0.1 \\
\hline 162.70 & 5.52 & 16.1 & 0.6 & 45.4 & 37.7 & 0 & 0.3 & 0 \\
\hline 167.20 & 2.40 & 5.4 & 1.5 & 35.3 & 57.8 & 0 & 0.1 & 0 \\
\hline 172.20 & 1.77 & 2.4 & 1.5 & 24.3 & 71.1 & 0 & 0.2 & 0.6 \\
\hline 176.69 & 1.50 & 6.7 & 1.3 & 34.3 & 57.6 & 0 & 0 & 0 \\
\hline 178.89 & 1.50 & 3.1 & 1.0 & 36.0 & 59.2 & 0 & 0.4 & 0.2 \\
\hline 184.68 & 4.46 & 3.1 & 2.3 & 60.4 & 33.8 & 0 & 0.2 & 0.2 \\
\hline 186.20 & 3.75 & 3.7 & 0.7 & 38.6 & 56.9 & 0 & 0.1 & 0 \\
\hline 189.64 & 10.39 & 46.4 & 0.3 & 43.7 & 9.4 & 0 & 0 & 0.1 \\
\hline 197.99 & 6.71 & 40.7 & 1.0 & 34.4 & 23.7 & 0 & 0 & 0.3 \\
\hline 199.09 & 4.60 & 18.8 & 1.0 & 32.7 & 47.5 & 0 & 0 & 0 \\
\hline 205.09 & 4.46 & 12.3 & 1.1 & 22.2 & 64.0 & 0 & 0.2 & 0.2 \\
\hline 208.73 & 9.49 & 7.3 & 0.2 & 32.2 & 60.2 & 0 & 0 & 0.1 \\
\hline 216.13 & 12.97 & 9.0 & 0.2 & 47.7 & 42.9 & 0.1 & 0 & 0.1 \\
\hline 218.15 & 6.72 & 6.3 & 0.1 & 38.5 & 54.7 & 0.1 & 0 & 0.3 \\
\hline 220.81 & 10.29 & 8.7 & 0.6 & 56.8 & 33.6 & 0 & 0 & 0.3 \\
\hline 228.56 & 8.81 & 40.4 & 0.5 & 42.4 & 16.6 & 0 & 0 & 0 \\
\hline 231.92 & 2.91 & 2.8 & 0.4 & 13.5 & 83.2 & 0 & 0 & 0 \\
\hline 237.23 & 10.99 & 36.1 & 0.2 & 34.7 & 28.9 & 0 & 0 & 0.1 \\
\hline 256.14 & 0.61 & 5.3 & 2.0 & 14.9 & 77.4 & 0 & 0.2 & 0.2 \\
\hline 259.09 & 2.62 & 46.2 & 0.3 & 33.1 & 20.1 & 0 & 0.3 & 0 \\
\hline 261.79 & 5.19 & 23.9 & 0.8 & 37.6 & 37.6 & 0 & 0.2 & 0 \\
\hline 267.31 & 3.17 & 49.5 & 0.5 & 34.0 & 15.5 & 0 & 0 & 0.5 \\
\hline 270.30 & 0.86 & 2.0 & 0.8 & 3.0 & 93.9 & 0 & 0.3 & 0 \\
\hline
\end{tabular}

Note: Sand-sized particles expressed as weight percentage of total sample, and individual constituents of sand fraction expressed as percentage of number of total sand particles. 
Table 2. Individual constituents of fine fraction in the calcareous sediments of the Ontong Java Plateau.

\begin{tabular}{|c|c|c|c|c|c|c|c|c|c|}
\hline $\begin{array}{l}\text { Depth } \\
\text { (mbsf) }\end{array}$ & $\begin{array}{c}\text { Nannofossils } \\
(\%)\end{array}$ & $\begin{array}{l}\text { Foraminifer } \\
\text { fragments } \\
(\%)\end{array}$ & $\begin{array}{l}\text { Unidentified } \\
\text { calcareous } \\
\text { particles }(\%)\end{array}$ & $\begin{array}{l}\text { Radiolarians } \\
\qquad(\%)\end{array}$ & $\begin{array}{l}\text { Diatoms } \\
(\%)\end{array}$ & $\begin{array}{c}\text { Organic } \\
\text { carbon } \\
(\%)\end{array}$ & $\begin{array}{l}\text { Unidentified } \\
\text { minerals } \\
(\%)\end{array}$ & $\begin{array}{l}\text { Unidentified } \\
\text { siliceous } \\
\text { particles }(\%)\end{array}$ & Preservation \\
\hline 5.07 & 89 & 3 & 7 & $<1$ & $<1$ & $<1$ & $<1$ & $<1$ & Good \\
\hline 6.49 & 50 & 4 & 6 & $<1$ & $<1$ & $<1$ & $<1$ & $<1$ & Good \\
\hline 9.46 & 90 & 3 & 5 & $<1$ & 1 & $<1$ & $<1$ & $<1$ & Good \\
\hline 20.59 & 88 & 2 & 8 & $<1$ & $<1$ & $<1$ & $<1$ & 1 & Good \\
\hline 24.10 & 88 & 3 & 8 & $<1$ & $<1$ & $<1$ & $<1$ & $<1$ & Good \\
\hline 25.51 & 89 & 5 & 5 & $<1$ & $<1$ & $<1$ & $<1$ & $<1$ & Good \\
\hline 30.79 & 87 & 5 & 6 & $<1$ & $<1$ & $<1$ & $<1$ & 1 & Good \\
\hline 33.11 & 87 & 5 & 5 & $<1$ & 1 & $<1$ & $<1$ & 1 & Good \\
\hline 38.10 & 88 & 6 & 5 & $<1$ & $<1$ & $<1$ & $<1$ & $<1$ & Good \\
\hline 39.60 & 88 & 5 & 5 & $<1$ & 1 & $<1$ & $<1$ & $<1$ & Good \\
\hline 43.36 & 65 & $<1$ & 25 & $<1$ & $<1$ & 0 & 9 & $<1$ & Good \\
\hline 44.89 & 88 & 3 & 6 & $<1$ & 1 & $<1$ & $<1$ & 1 & Good \\
\hline 46.35 & 83 & 3 & 10 & $<1$ & $<1$ & $<1$ & 3 & $<1$ & Good \\
\hline 46.46 & 89 & 4 & 4 & $<1$ & 1 & $<1$ & $<1$ & 1 & Good \\
\hline 48.70 & 83 & 5 & 10 & $<1$ & $<1$ & 0 & 1 & $<1$ & Good \\
\hline 51.70 & 80 & 1 & 15 & $<1$ & 2 & 0 & 2 & $<1$ & Good \\
\hline 62.70 & 86 & 2 & 9 & $<1$ & 1 & $<1$ & $<1$ & 1 & Good \\
\hline 73.68 & 85 & $<1$ & 12 & $<1$ & $<1$ & $<1$ & $<1$ & $<1$ & Good \\
\hline 75.60 & 85 & 1 & 10 & 1 & 2 & 0 & 1 & $<1$ & Good \\
\hline 77.17 & 86 & 1 & 10 & $<1$ & 1 & $<1$ & $<1$ & 1 & Good \\
\hline 83.19 & 85 & 1 & 10 & 1 & 2 & 0 & 1 & $<1$ & Good \\
\hline 83.95 & 85 & $<1$ & 8 & 2 & 2 & 0 & $<1$ & 2 & Good \\
\hline 88.18 & 87 & 1 & 8 & 1 & 1 & 0 & $<1$ & 2 & Good \\
\hline 89.69 & 87 & 1 & 7 & 2 & 1 & 0 & $<1$ & 1 & Good \\
\hline 93.46 & 86 & 1 & 8 & 2 & 2 & 0 & $<1$ & $<1$ & Good \\
\hline 94.70 & 88 & 1 & 5 & 1 & 2 & $<1$ & 1 & 2 & Good \\
\hline 100.70 & 87 & $i$ & 7 & 1 & 1 & 0 & $<1$ & 2 & Good \\
\hline 107.17 & 87 & $i$ & 7 & $i$ & $i$ & 0 & 1 & 2 & Good \\
\hline 111.68 & 88 & 2 & 7 & 0 & 2 & $<1$ & $<1$ & $<1$ & Good \\
\hline 115.14 & 88 & 4 & 4 & 0 & 3 & 0 & $<1$ & $<1$ & Good \\
\hline 118.51 & 87 & 1 & 7 & 2 & 2 & $<1$ & $<1$ & $<1$ & Good \\
\hline 119.58 & 87 & 4 & 6 & 0 & 2 & 0 & $<1$ & $<1$ & Good \\
\hline 123.20 & 89 & 2 & 4 & 0 & 4 & 0 & $<1$ & $<1$ & Good \\
\hline 124.68 & 82 & 5 & 9 & $<1$ & 2 & $<1$ & 1 & $<1$ & Good \\
\hline 127.69 & 50 & 1 & 16 & $-\mathrm{cl}$ & 1 & $<1$ & 1 & $<1$ & Moderate/good \\
\hline 129.13 & 82 & 5 & 7 & $-\mathrm{cl}$ & 5 & $<1$ & $<1$ & $<1$ & Good \\
\hline 135.70 & 82 & 4 & 6 & $<1$ & 4 & $<1$ & 2 & 1 & Moderate \\
\hline 138.68 & 81 & 10 & 7 & $<1$ & 1 & $<1$ & $<1$ & $<1$ & Good \\
\hline 140.19 & 84 & 4 & 9 & $<1$ & 1 & $-\mathrm{cl}$ & $<1$ & $<1$ & Moderate \\
\hline 145.17 & 81 & 3 & 12 & 0 & 2 & 0 & 1 & 1 & Moderate/good \\
\hline 148.20 & 85 & 3 & 8 & $<1$ & 3 & $<1$ & $<1$ & $<1$ & Moderate/good \\
\hline 149.59 & 50 & 2 & 14 & $<1$ & 2 & $<1$ & I & 1 & Moderate/good \\
\hline 154.69 & 84 & 3 & 8 & $<1$ & 4 & $<1$ & $<1$ & $<1$ & Moderate/good \\
\hline 162.70 & 86 & 3 & 7 & $<1$ & 3 & $<1$ & $<1$ & $<1$ & Moderate \\
\hline 167.20 & 86 & 2 & 8 & $<1$ & 3 & $<1$ & $<1$ & $<1$ & Moderate/good \\
\hline 172.20 & 87 & 2 & 8 & $<1$ & 1 & 0 & 0 & 1 & Good \\
\hline 176.69 & 86 & $i$ & 9 & $<1$ & 2 & 0 & $<1$ & 1 & Good \\
\hline 178.89 & 86 & 2 & 8 & $<1$ & 3 & $<1$ & $<1$ & $<1$ & Moderate/good \\
\hline 184.68 & 87 & 1 & 9 & $<1$ & 2 & 0 & $<1$ & 1 & Good \\
\hline 186.20 & 88 & 1 & 8 & $<1$ & 2 & 0 & $<1$ & 1 & Good \\
\hline 189.64 & 87 & $i$ & 9 & $<1$ & 1 & 0 & $<1$ & $i$ & Moderate/good \\
\hline 197.99 & 88 & 1 & 8 & $-\mathrm{cl}$ & $<1$ & 0 & $<1$ & 2 & Moderate/poor \\
\hline 199.09 & 88 & 1 & 5 & 1 & 3 & 0 & $<1$ & I & Moderate \\
\hline 205.09 & 70 & 1 & 10 & 2 & 10 & 0 & $<1$ & 7 & Moderate/good \\
\hline 208.73 & 70 & $i$ & 7 & 1 & 10 & 0 & 1 & 10 & Moderate/good \\
\hline 216.13 & 75 & $<1$ & 5 & 2 & 10 & 0 & $i$ & 7 & Moderate/good \\
\hline 218.15 & 75 & 1 & 4 & 3 & 10 & 0 & $<1$ & 7 & Moderate \\
\hline 220.81 & 80 & $i$ & 3 & 2 & 8 & $<1$ & $<1$ & 5 & Moderate \\
\hline 228.56 & 80 & 2 & 10 & 1 & 5 & $<1$ & $<1$ & 1 & Moderate \\
\hline 231.92 & 82 & 2 & 8 & 1 & 5 & $<1$ & $<1$ & $i$ & Moderate/good \\
\hline 237.23 & 82 & 3 & 8 & 1 & 5 & $<1$ & $<1$ & $<1$ & Moderate/good \\
\hline 256.14 & 84 & 3 & 9 & $<1$ & 2 & $<1$ & $<1$ & 1 & Moderate/good \\
\hline 259.09 & 85 & 5 & 9 & $<1$ & $<1$ & 0 & $<1$ & $<1$ & Moderate/good \\
\hline 261.79 & 85 & 4 & 6 & $<1$ & 2 & 0 & $<1$ & 2 & Good \\
\hline 267.31 & 84 & 5 & 7 & $<1$ & 2 & 0 & $<1$ & 1 & Good \\
\hline 270.30 & 85 & 4 & 8 & $<1$ & 1 & $<1$ & $<1$ & i & Good \\
\hline
\end{tabular}

Note: Values are expressed as percentage of number of total fine particles. 

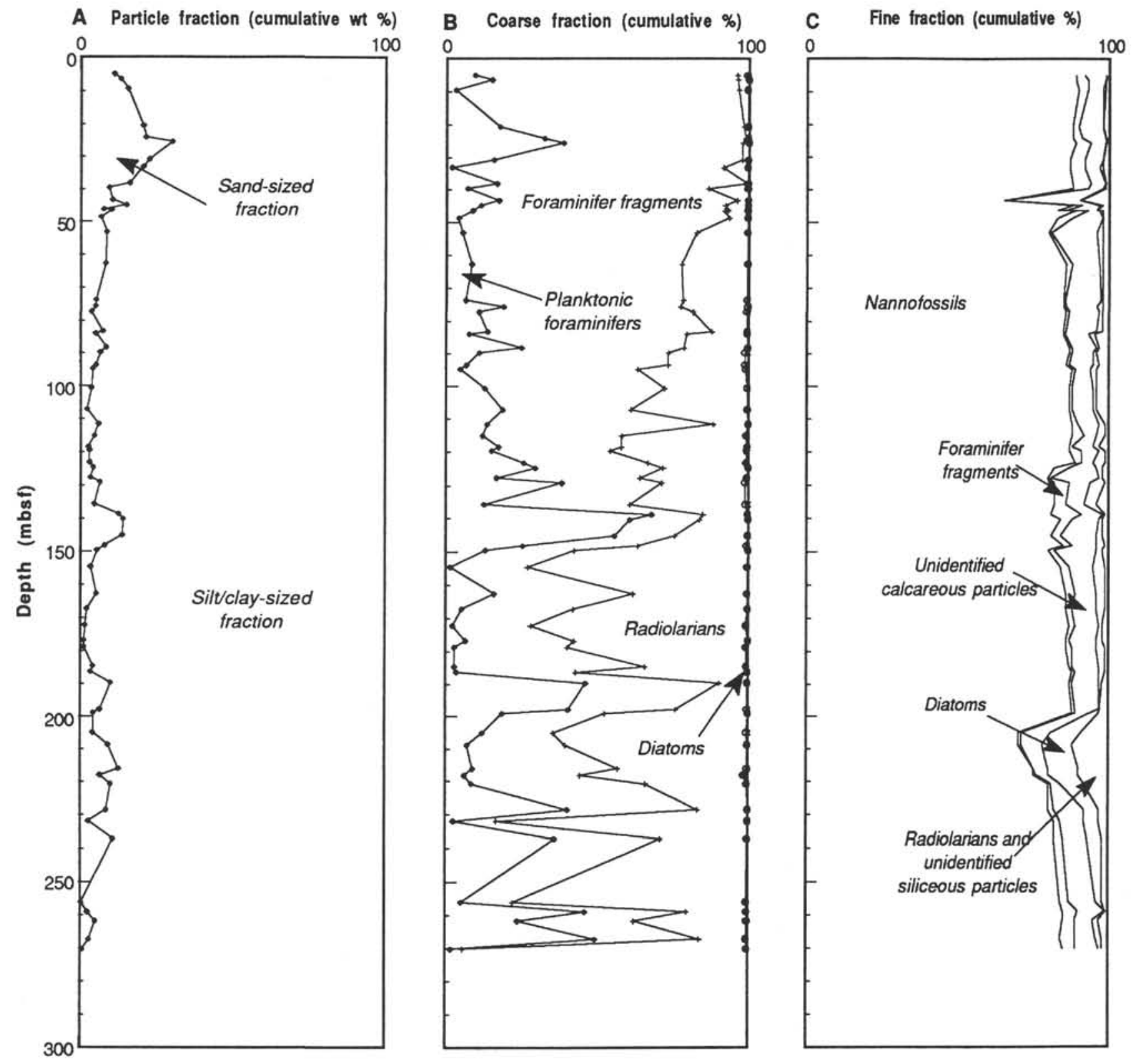

Figure 2. A. Grain size vs. depth for the samples analyzed in this study. Sand-sized fraction is the percent by weight retained on a $63-\mu \mathrm{m}$ sieve. B. Relative percentages of the four major components of the coarse fraction. C. Relative percentages of the fine fraction constituents.

trend; this implies that dissolution after burial is sufficient to affect the number of fragments but not result in a significant decrease in whole planktonic foraminifers.

Because the foraminifer fragments and radiolarians show these trends with depth, we have corrected the data for these constituents using a method similar to that used to correct for depth trends caused by compaction in the physical properties data. Foraminifer fragments and radiolarians are plotted vs. depth in Figure 3. In each case, we have applied a polynomial fit to the actual data and then shifted the data by the difference between the fit and the porosity of the deepest sample. The corrected data are shown as the dashed line in Figure 3. Thus, we have corrected the data in the shallower depths to have similar degrees of dissolution as those of the deepest sample analyzed. The deeper sample value was used as a baseline to preclude data being shifted outside the $0 \%-100 \%$ range. Planktonic foraminifer data were also corrected, but the slight change in the real data with depth makes the correction insignificant.
Imprinted on these general trends are zones with higher planktonic foraminifer content and lower radiolarian counts (e.g., 138-145 and 190-198 mbsf). These zones presumably represent less dissolution of $\mathrm{CaCO}_{3}$ than experienced by other samples, which may result from a lowering of the lysocline at the time of deposition.

Nannofossils are the primary constituents of the fine fraction, usually numbering $>80 \%$ of the fine particles (Fig. 2C). Foraminifer fragments generally number $<5 \%$ of the fine fraction; unidentified calcareous particles number between $5 \%$ and $10 \%$; diatoms, radiolarians, and unidentified siliceous particles generally number $<3 \%$ of the fine particles. No obvious trends with depth were observed for the fine fraction constituents. However, one notable interval occurs between 205 and $220 \mathrm{mbsf}$, in which the number of various siliceous particles increases to a total of approximately $20 \%$ of the fine particles. This interval corresponds to one of higher radiolarian content in the coarse fraction and presumably represents increased dissolution of $\mathrm{CaCO}_{3}$ (i.e., a shallower lysocline). 


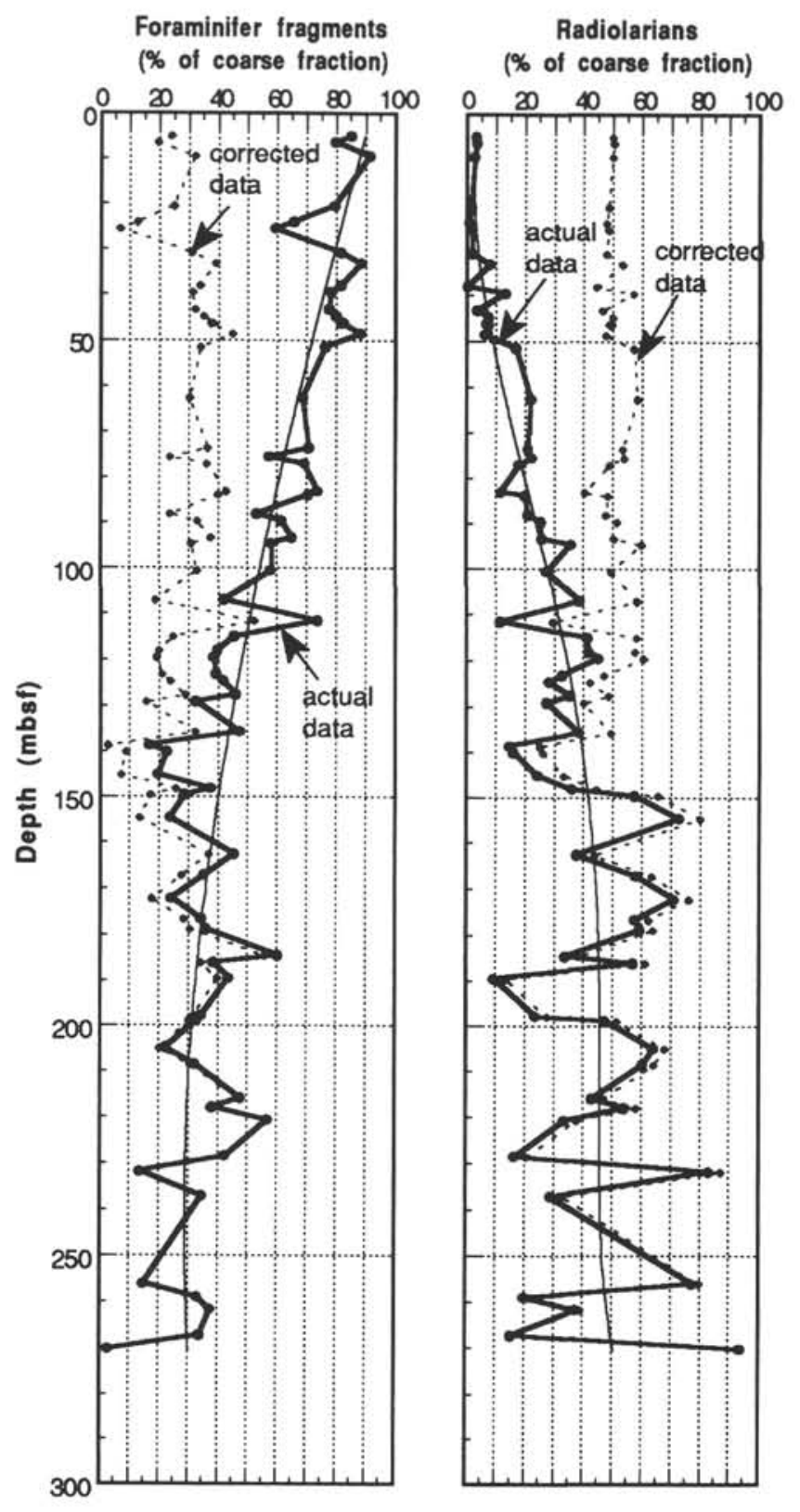

Figure 3. Two coarse fraction constituents (foraminifer fragments and radiolarians) vs. depth. Shown are actual data and data corrected for dissolution effects.

Previous studies (e.g., Hamilton et al., 1982; Bachman, 1984) have found that relationships between porosity and other properties, including velocity, grain size, and $\mathrm{CaCO}_{3}$ content, are difficult to establish for Ontong Java Plateau sediments. We have also found this to be true in our study. Porosity vs. weight percent of coarse particles (Fig. 4) shows no obvious relationship between porosity and grain size. Plots of porosity and velocity vs. abundance of individual microfossil constituents (Figs. 5 and 6, respectively) also show no obvious relationships.

\section{DISCUSSION}

The difficulty in establishing relationships between index properties data and velocity, carbonate content, or microfossil content is largely because of voids in the microfossil tests. Calcareous sediments react to the passage of sound waves as if they were composed of solid,

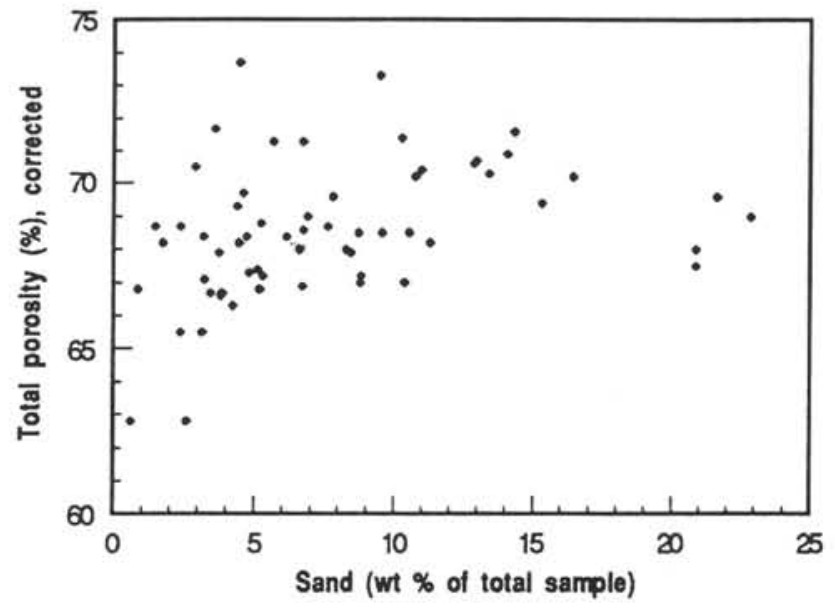

Figure 4. Total porosity vs. sand-sized content for the samples analyzed.

rather than hollow, particles (Gallagher, 1967; Hamilton et al., 1982). However, the methods used in the laboratory to determine index properties, such as porosity and bulk density, measure the total sample void space. The total sample porosity is made up of intraparticle porosity, defined by Choquette and Pray (1970) as porosity within individual grains or particles, and interparticle porosity, defined as the porosity between particles. In terrigenous sediments, consisting predominantly of solid particles, porosity increases with decreasing grain size (Schreiber, 1968; Johnson et al., 1977). As the grain size of foraminifer-rich sediment decreases, and the number of broken or severely corroded tests increases, intraparticle porosity is converted to interparticle porosity. However, the total porosity (as measured by shipboard procedures) remains approximately constant.

This phenomenon results in difficulty in determining relationships between the index properties and other parameters in this study, and has also plagued the studies of others. For example, Hamilton et al. (1982) found that porosity and density are good indexes to velocity in the deep, eastern equatorial Pacific, where calcium carbonate contents are lower, but they found no usable relationship between velocity and density or velocity and porosity in Ontong Java Plateau sediments. Hamilton et al. (1982) also found little relationship between percent $\mathrm{CaCO}_{3}$ and sound velocity or percent $\mathrm{CaCO}_{3}$ and bulk density for the plateau sediments. They found that impedance has a linear relationship with saturated bulk density in the eastern Pacific samples, but that the plateau samples diverge markedly from this trend.

The question remains, then, of how to link lysoclinal cycles to the seismic reflectors observed in these sediments (Kroenke et al., this volume). Berger and Mayer (1977) concluded that the origin of seismic reflectors must be tied to lithologic changes that cause quasicyclic impedance contrasts. Therefore, we should be able to establish a link between changes in microfossil content caused by lysoclinal changes and the variations in physical properties that cause impedance contrasts. However, the intraparticle porosity problem makes this extremely difficult.

J. Urmos (unpubl. data, 1991) has provided us with estimates of intraparticle porosity for the sample depths of our study. These estimates of intraparticle porosity were derived from analyses of porosity-velocity cross plots of downhole logging and shipboard data. Urmos assumed that different porosities in samples of the same velocity were the result of different amounts of intraparticle porosity. We have used these values of intraparticle porosity to calculate interparticle porosity (i.e., the porosity between the grains).

Plots of interparticle porosity vs. planktonic foraminifers, foraminifer fragments, and radiolarians are shown in Figure 7. A comparison of these porosity data with those of Figure 5, plotted at the same scale, show that the interparticle porosity data exhibit 

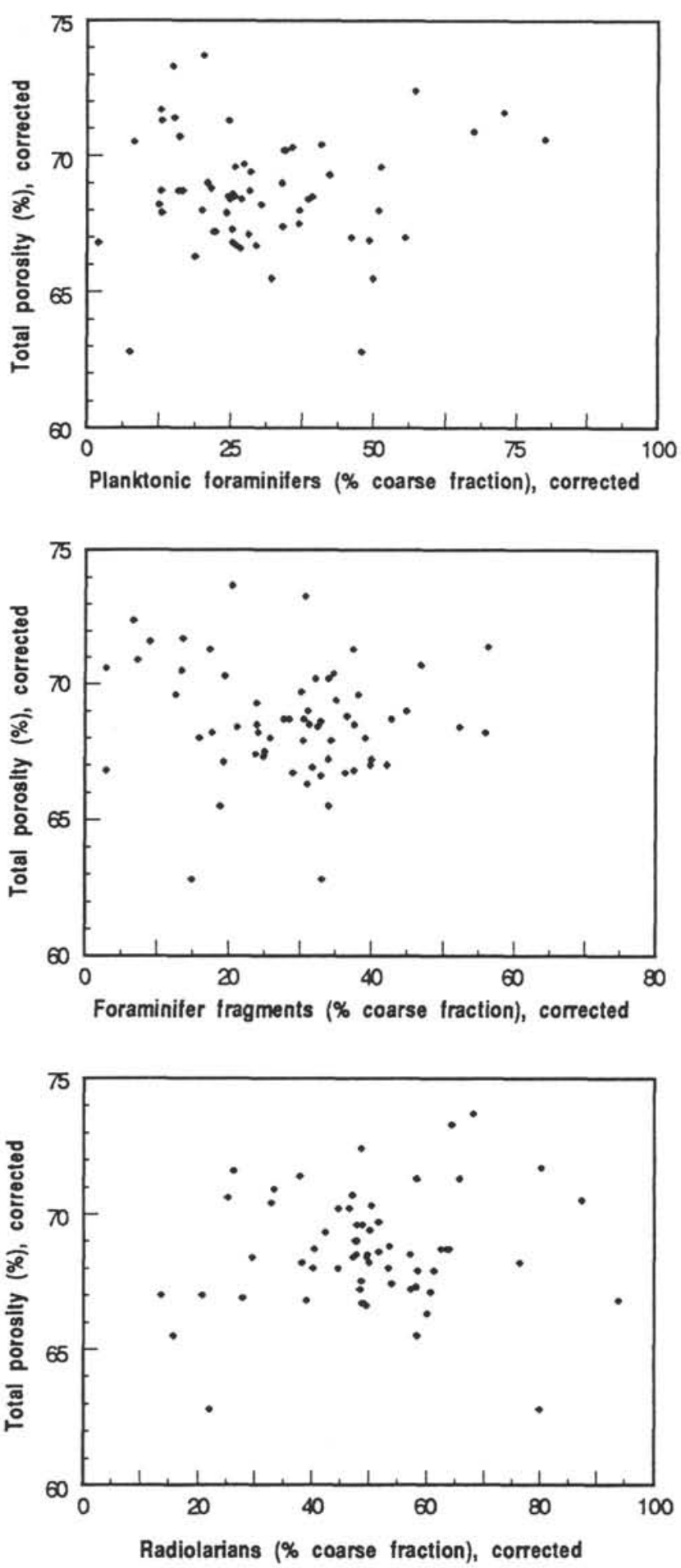

Figure 5. Total porosity vs. three individual microfossil constituents.

considerably less scatter. Although the range of porosities is small, a trend of decreasing interparticle porosity with increasing number of whole planktonic foraminifers was observed (Fig. 7A). Foraminifer fragments also exhibited a decrease with decreasing interparticle porosity (Fig. 7B). This relationship implies that the particles we denoted as fragments $(<50 \%$ complete) still contain intraparticle porosity that decreases as the fragments are subject to dissolution, similar to the behavior of the foraminifers we classified as whole. A relationship of increasing interparticle porosity with increasing radi-
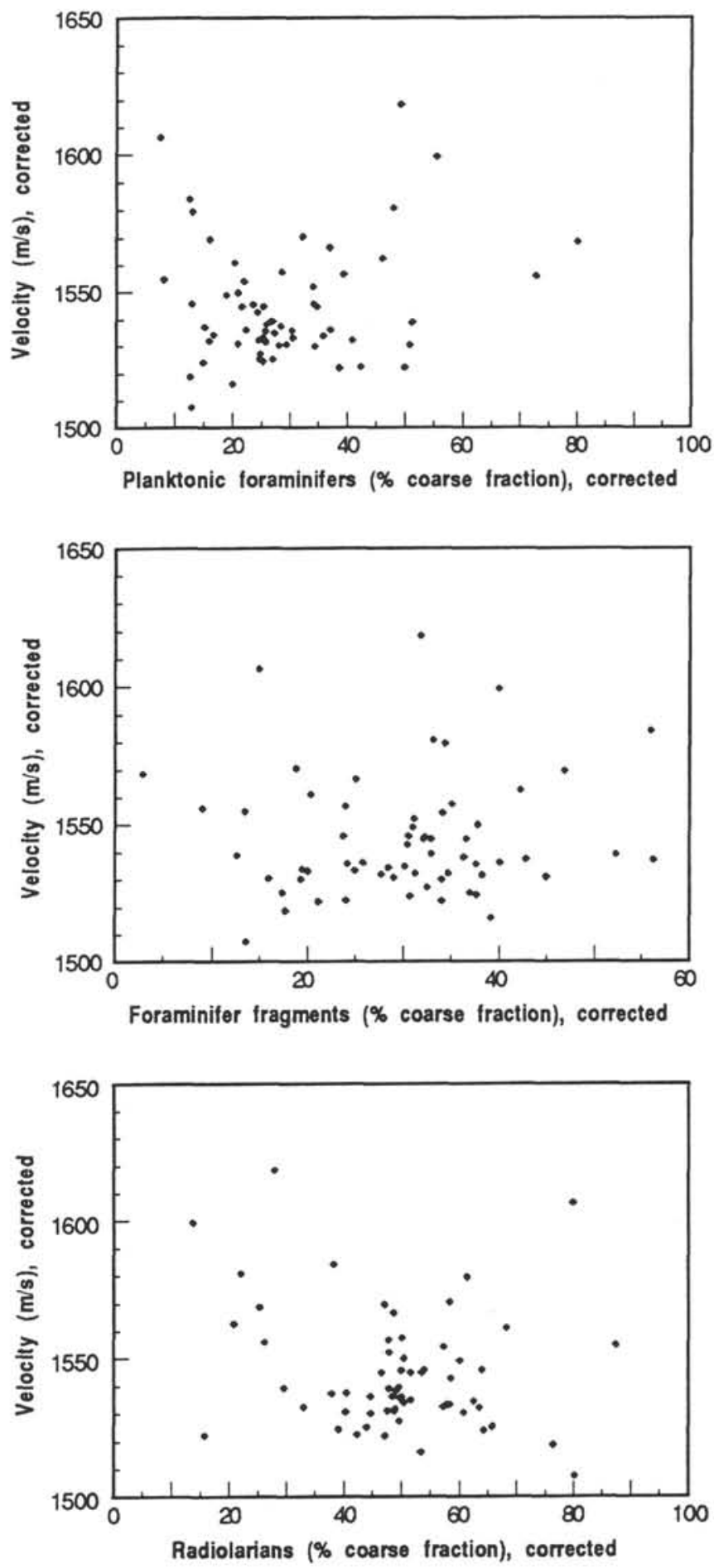

Figure 6. Compressional wave velocity vs. three individual microfossil constituents.

olarian content can be seen in Figure 7C. The calculated interparticle porosity vs. percentage coarse fraction is presented in Figure 8; it shows a clearer relationship with grain size than is observed with total porosity (Fig. 4). Again, the range of porosities is small, but a relationship of increasing interparticle porosity with decreasing grain size was observed, similar to the relationships observed for porosity and grain size in other sediment types (Johnson et al., 1977).

Shipboard lithologic descriptions (Kroenke, Berger, Janecek, et al., 1991) note a transition from soft to stiff ooze at approximately 
A

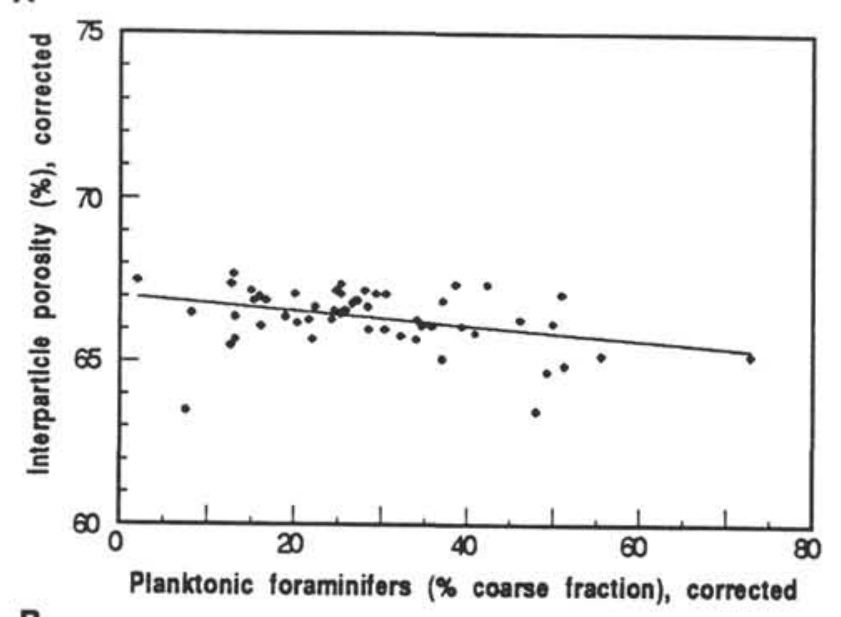

B

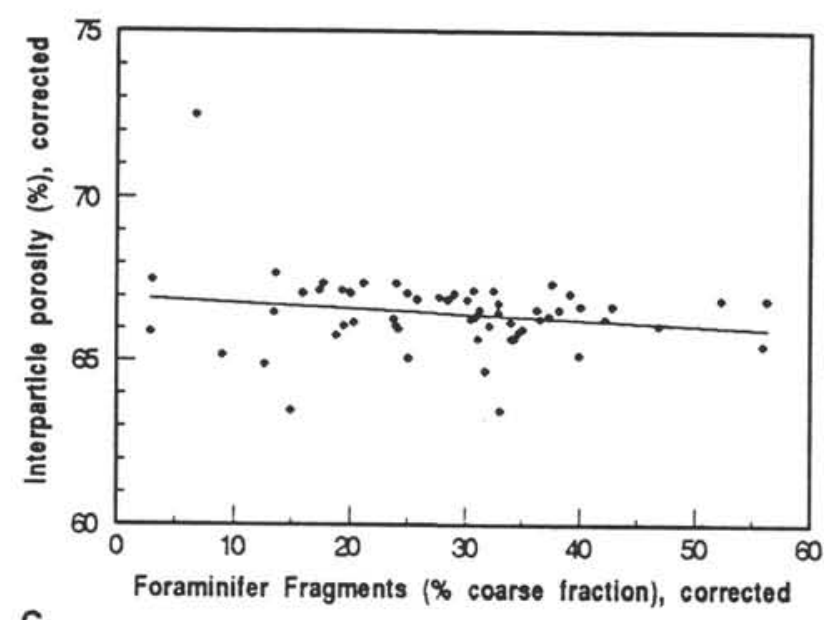

C

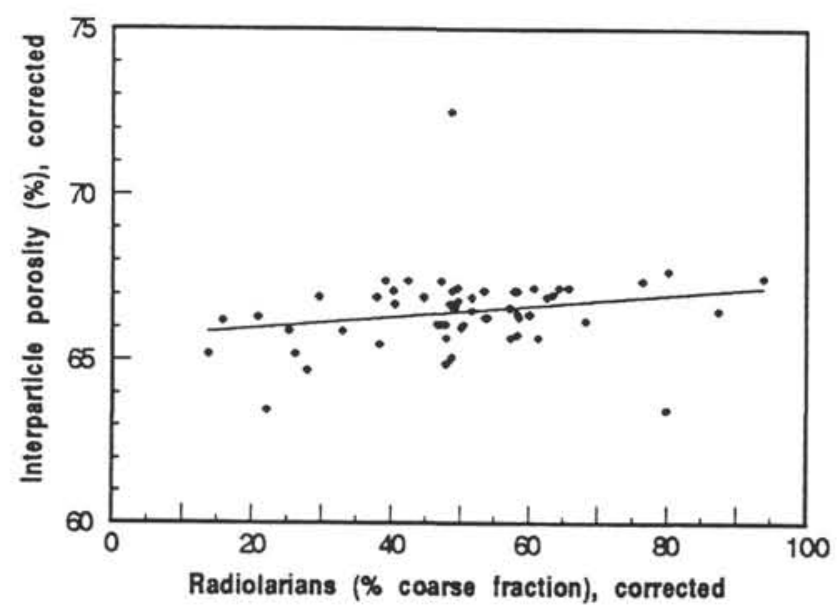

Figure 7. A. Interparticle porosity vs. percentage of planktonic foraminifers. The least-squares fit to the data has the equation: Porosity $=67.0-0.022(\%$ foraminifers); $R=0.34$. B. Interparticle porosity vs. percentage of foraminifer fragments. The least-squares fit to the data has the equation: Porosity $=67.0-$ 0.018 (\% foraminifer fragments); $R=0.18$. C. Interparticle porosity vs. percentage of radiolarians. The least-squares fit to the data has the equation: Porosity $=65.6+0.017$ (\% radiolarians) $R=0.23$.

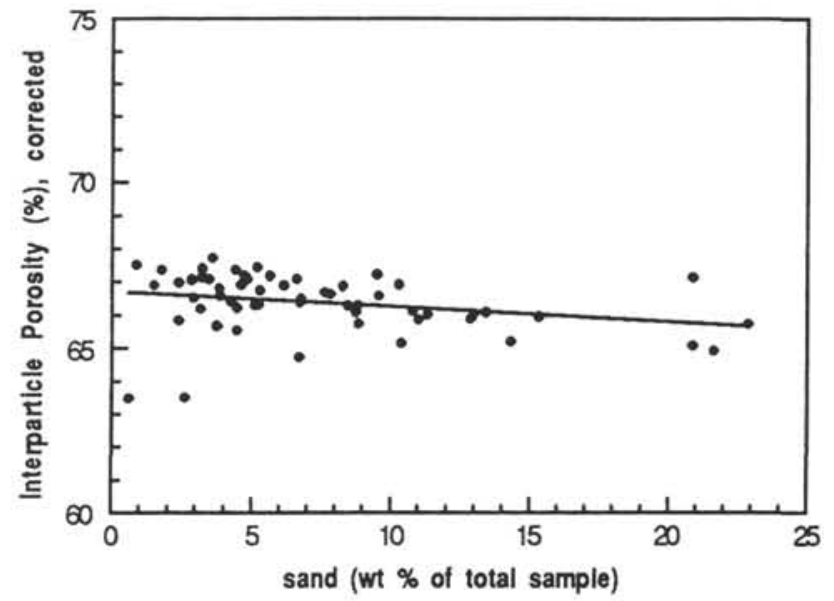

Figure 8. Interparticle porosity vs. percentage of coarse fraction. The least-squares fit to the data has the equation: Porosity $=66.7-0.046$ ( $\%$ sand); $R=0.27$.

150 mbsf. A seismic reflection horizon is also located at this depth, which corresponds to the approximate depth of a significant change in the relative numbers of the coarse fraction microfossil constituents (Fig. 2B). Near $150 \mathrm{mbsf}$, a sharp decrease in the number of planktonic foraminifers and a sharp increase in the number of radiolarians occurs. In general, radiolarian content remains high (often $>50 \%$ of the coarse particles) below $150 \mathrm{mbsf}$.

Increased scatter in velocity data in stiffer oozes was attributed by Bassinot et al. (this volume) to increased measurement error as a result of cracking of the sediment upon insertion of the DSV transducer probes. Plots of velocity vs. coarse fraction microfossil constituents (Fig. 9) show that the significant scatter observed in the velocity plots of Figure 6 is somewhat a result of scatter in the data from depths below $150 \mathrm{mbsf}$. However, the velocity vs. constituent plots for depths shallower than $150 \mathrm{mbsf}$ also exhibit considerable scatter. Velocity vs. grain size (Fig. 10) for samples in the upper $150 \mathrm{~m}$ does exhibit a relationship of increasing velocity with increasing grain size, as observed in other studies (Hamilton et al., 1982; Mayer, 1979; Schreiber, 1968).

Mayer (1979) examined the relationships between acoustic, stratigraphic, and physical properties of deep-sea carbonates from the eastern equatorial Pacific and determined that variations in acoustic impedance in oozes are almost entirely controlled by changes in saturated bulk density (or its inverse, porosity), and that velocity changes are very small. Shipboard laboratory velocity data and downhole logging data obtained during Leg 130 also indicate that velocity changes are very small in the oozes. Impedance changes are obviously closely linked to density changes for the Ontong Java Plateau oozes (Fig. 11).

Impedance was calculated for sediments in the upper $150 \mathrm{mbsf}$ to avoid the scatter in the velocity data below this depth. Bulk density calculated using interparticle porosity was also used. Plots displaying slightly increasing impedance with increasing planktonic foraminifers and slightly decreasing impedance with increasing radiolarian content (Fig. 12) mirror the relationships between interparticle porosity and the same microfossil constituents (Fig. 7). This relationship would be expected if impedance is controlled by variations in density and if density is considered an inverse of porosity. Impedance is plotted vs. sand-sized particles in Figure 13. The relationship of increased impedance with increased grain size was also observed by Berger and Mayer (1977).

An interesting result of this study is that no relationships were found between physical properties parameters and variations in the fine fraction $(<63 \mu \mathrm{m})$ constituents (Fig. 14). The fine fraction constituents make up $>85 \%$ of the total sample by weight. However, it 
A

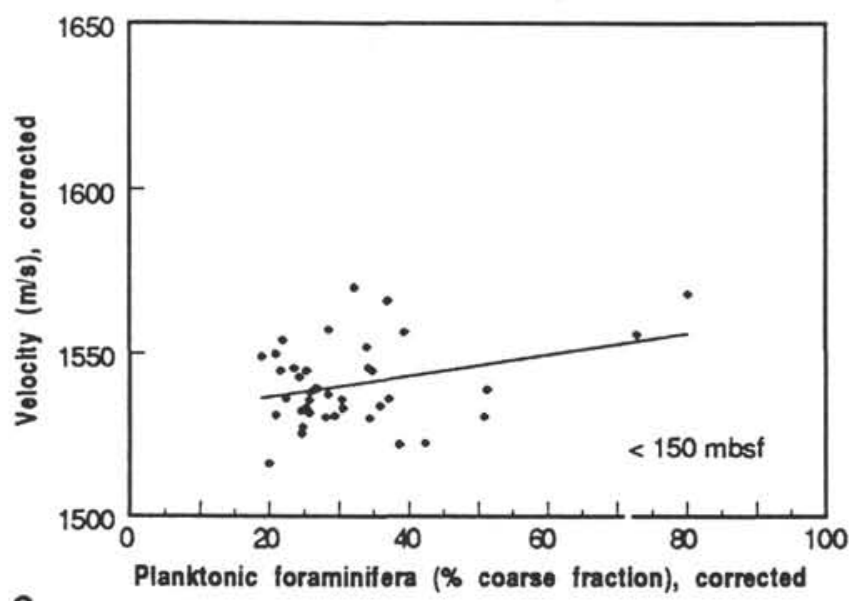

C

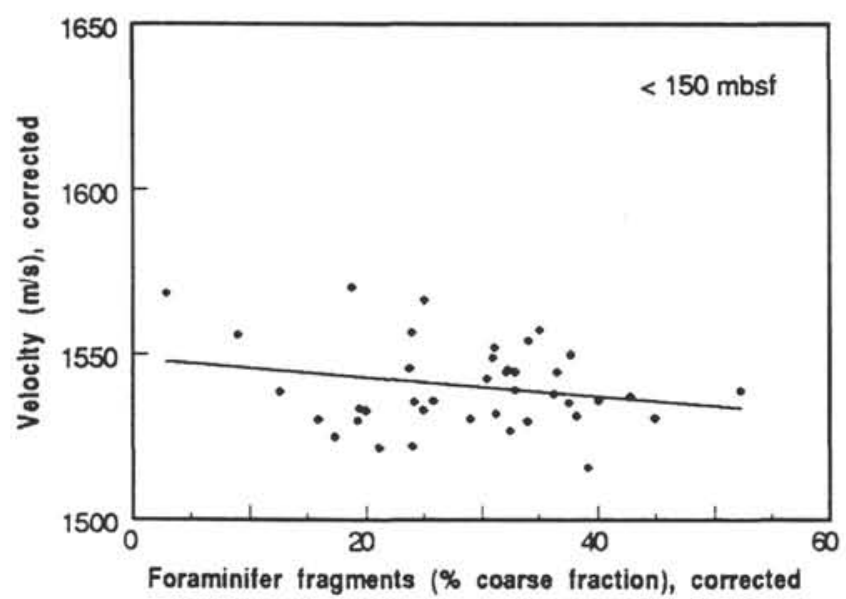

E

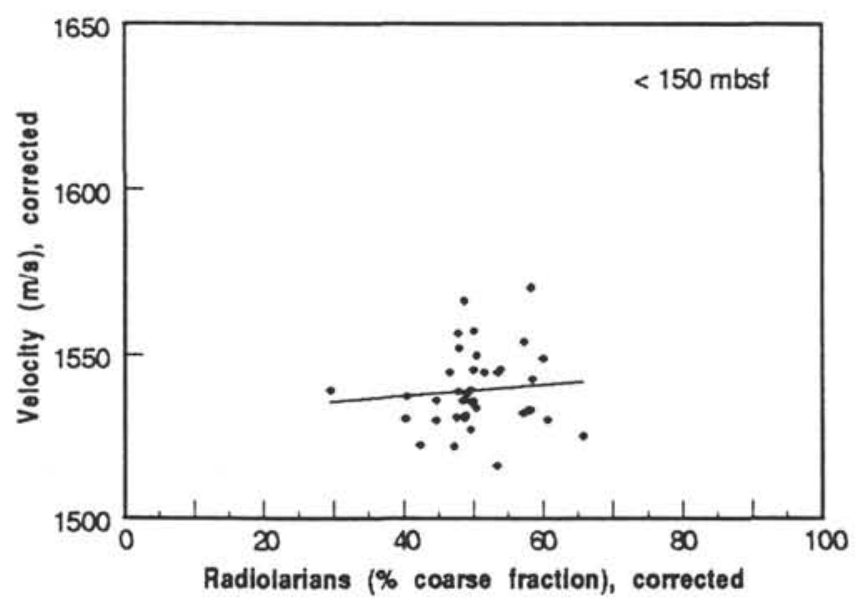

B

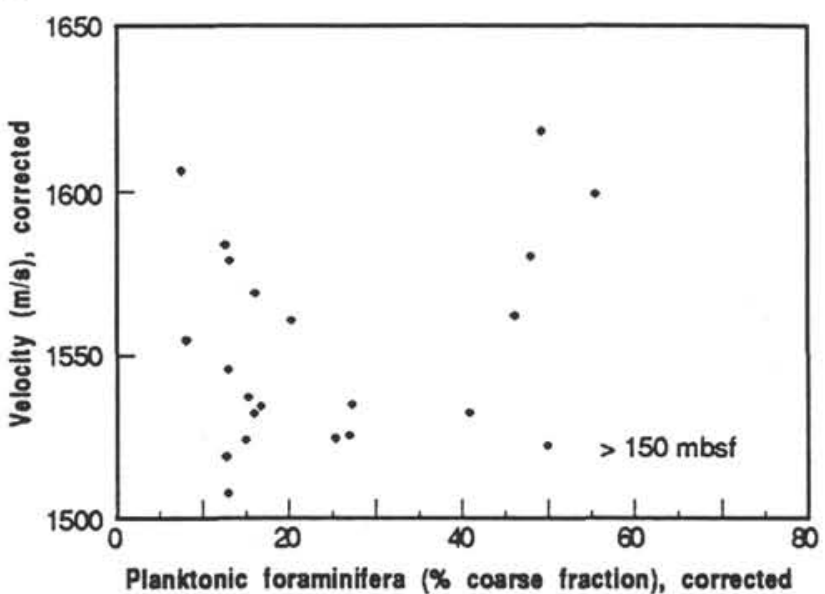

D

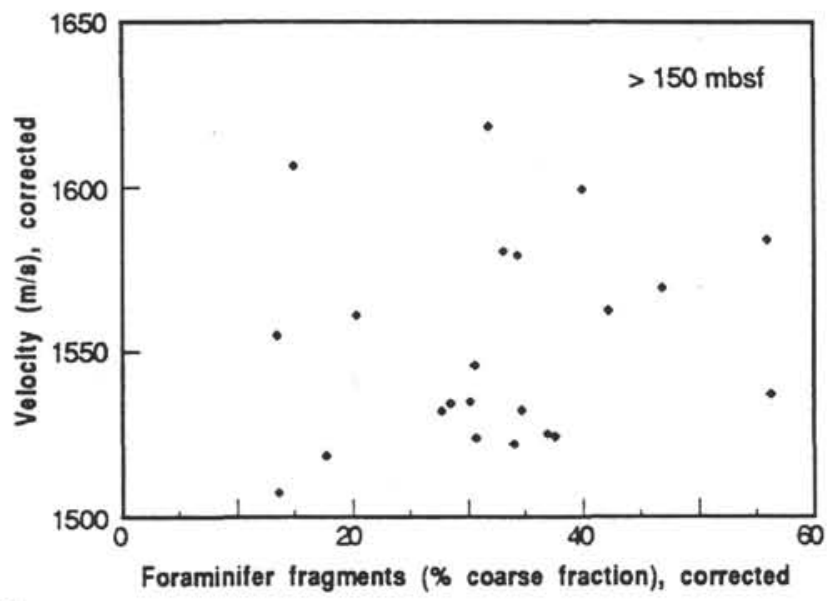

F

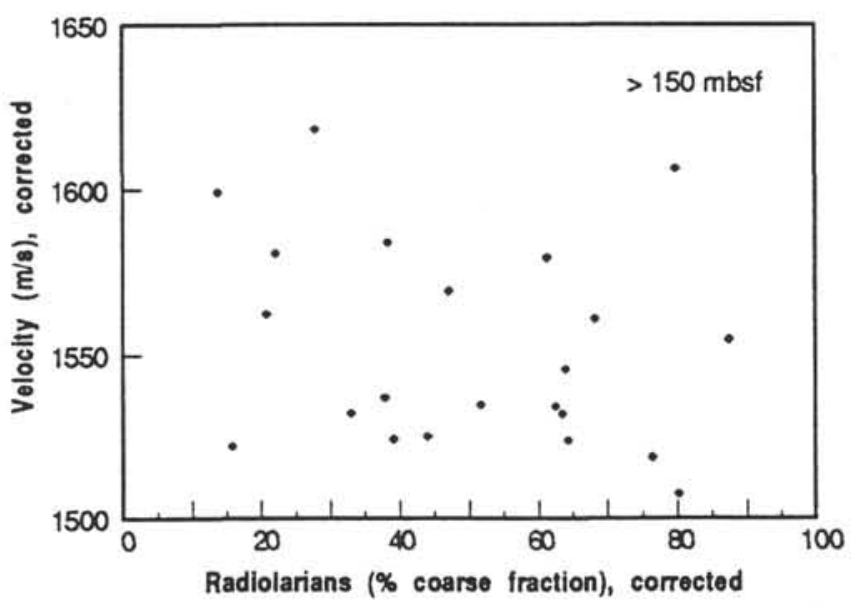

Figure 9. A. Velocity vs. percentage of planktonic foraminifers for samples from depths $<150 \mathrm{mbsf}$. The least-squares fit to the data has the equation: Velocity $=$ $1530+0.33$ ( $\%$ foraminifers); $R=0.33$. B. Velocity vs. percentage of planktonic foraminifers for samples from depths $>150$ mbsf. C. Velocity vs. percentage of foraminifer fragments for samples from depths $<150 \mathrm{mbsf}$. The least-squares fit to the data has the equation: Velocity $=1548-0.28$ (\% foraminifers); $R=0.22$. D. Velocity vs. percentage of foraminifer fragments for samples from depths $<150 \mathrm{mbsf}$. E. Velocity vs. percentage of radiolarians for samples from depths $<150$ mbsf. The least-squares fit to the data has the equation: Velocity $=1530-0.18$ (\% radiolarians); $R=0.10$. F. Velocity vs. percentage of radiolarians for samples from depths $>150$ mbsf. 


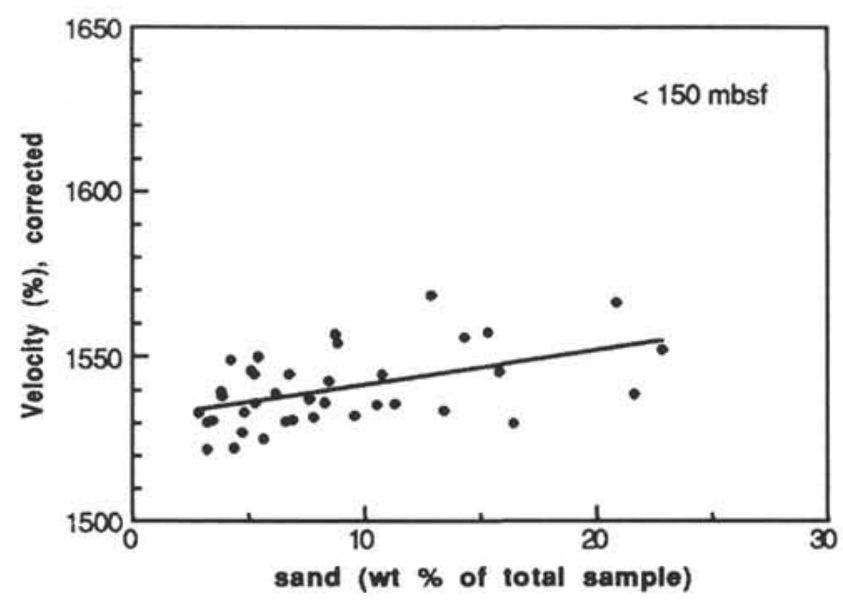

Figure 10. Velocity vs. percentage of coarse fraction. The least-squares fit to the data has the equation: Velocity $=1531+1.037$ (\% sand); $R=0.49$.

appears that any variations in the physical properties as a result of changes in microfossil constituents are controlled by changes in the relative percentages of the coarse fraction constituents.

A concern in relating seismic reflectors to preservation as a result of shifts in the lysocline is the degree of dissolution that occurs after burial. Berger and Johnson (1976) concluded that the depth dependence of the number and spacing of reflectors suggest that dissolution in the water column and at the sediment-water interface is the primary agent controlling the profiles. It seems likely that in a sediment system so highly saturated in $\mathrm{CaCO}_{3}$, only minor, if any, dissolution of buried tests would occur until overburden pressures became high enough for pressure solution at grain contacts. Preservation in this study was judged as moderate if some of the discoasters were coated with secondary calcite growth. Overgrowth did not appear to affect the coccoliths. Preservation is described as good in the upper $125 \mathrm{~m}$; below that depth, it ranges from moderate to good. We conclude that the dissolution responsible for the fluctuations in microfossil content in the sediment column occurred predominantly in the water column and at the sediment-water interface. However, dissolution after burial does result in a slight decrease of foraminifer fragments with depth, and a corresponding increase in the percentage of radiolarians in the samples.

\section{CONCLUSIONS}

Relationships were observed in this study that can be used to link lysoclinal shifts to changes in physical properties. However, the role of intraparticle porosity in these highly calcareous sediments makes the use of index properties data as habitually determined on the ship inappropriate. Calculation of interparticle porosity provides relationships between interparticle porosity and microfossil constituents, or grain size, and between impedance and microfossil constituents. Strong relationships were not observed in this study because of the small range of values for most of the physical properties parameters for this site.

Velocity data below 150 mbsf show significant scatter because of measurement problems in the stiffer ooze. Clearer relationships were observed for velocity and impedance data for depths shallower than $150 \mathrm{mbsf}$. Using the corrections for interparticle porosity, impedance data for samples in the upper $150 \mathrm{mbsf}$ were found to increase with grain size.

The fine fraction $(<63 \mu \mathrm{m})$ constituents make up $>85 \%$ of the samples by weight. However, no relationships were observed between variations in fine-fraction constituents and variations in physical properties. It appears that the variations in the coarse-fraction constituents exert more control over physical properties.
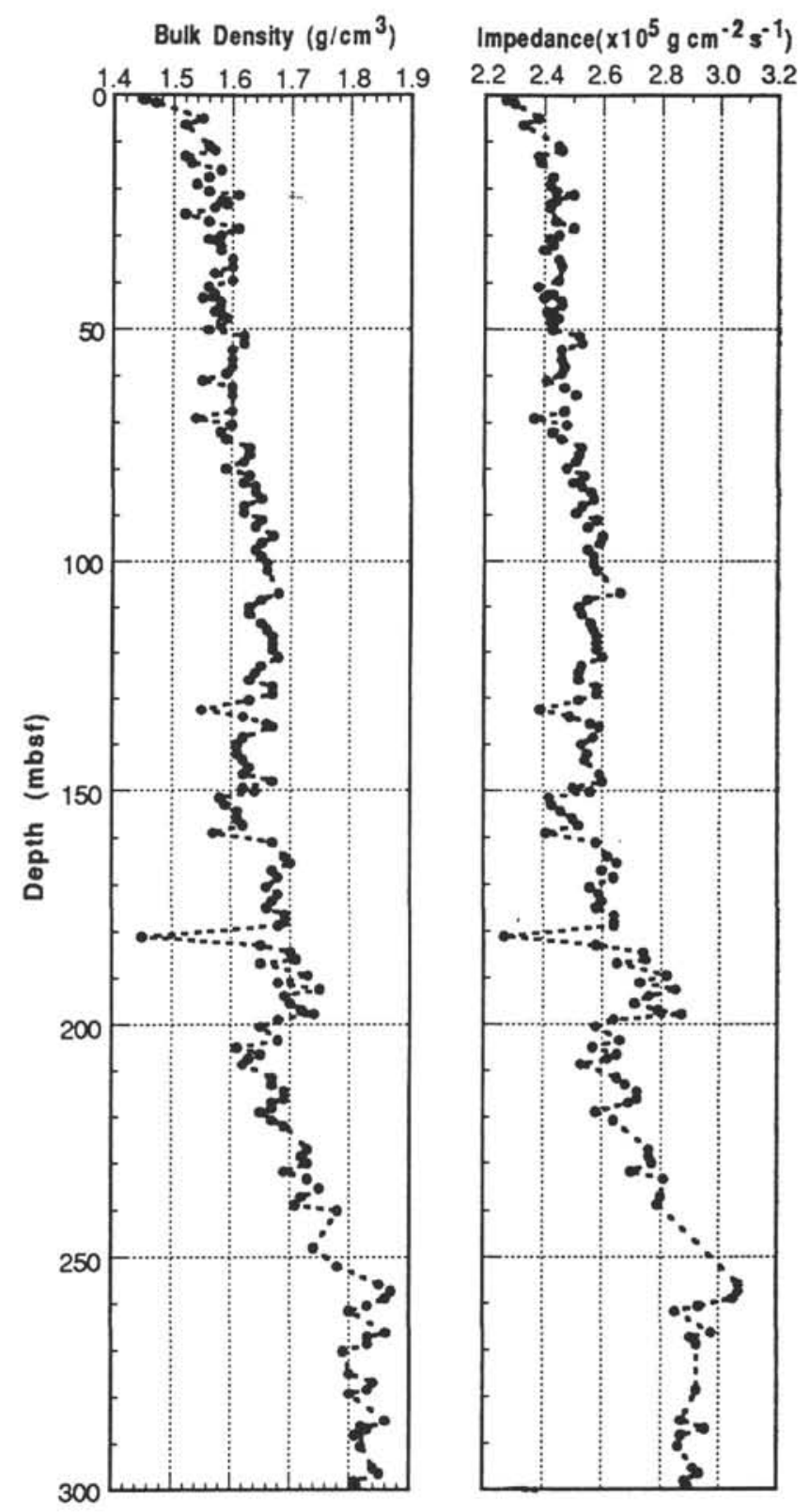

Figure 11. Bulk density and impedance vs. depth for the samples studied.

\section{ACKNOWLEDGMENTS}

The authors gratefully acknowledge the assistance of Garen Ito in sample preparation, and thank reviewers Jane Tribble and Richard Bachman for their constructive comments. The research was supported by USSAC post-cruise funding. This manuscript is SOEST Contribution No. 2967.

\section{REFERENCES}

Bachman, R.T., 1984. Intratest porosity in foraminifera. J. Sediment. Petrol., $54: 257-262$.

Berger, W.H., 1976. Biogenous deep-sea sediments: production, preservation and interpretation. In Riley, J.P., and Chester, R. (Eds.), Treatise on Chemical Oceanography: London (Academic Press), 265-388.

Berger, W.H., and Mayer, L.A., 1977. Deep-sea carbonates: acoustic reflectors and lysocline fluctuations. Geology, 6:11-15.

Boyce, R.E., 1976. Definitions and laboratory techniques of compressional sound velocity parameters and wet water content, wet bulk density and 
porosity parameters by gravimetric and gamma ray attenuation techniques. In Schlanger, S.O., Jackson, E.D., et al., Init. Repts. DSDP, 33: Washington (U.S. Govt. Printing Office), 931-958.

Choquette, P.W., and Pray, L.C., 1970. Geologic nomenclature and classification of porosity in sedimentary carbonates. AAPG Bull., 54:207-250.

Gallagher, J.J., 1967. Influence of hollow shells on the porosity-sound velocity relationship in some marine sediments. J. Acoust. Soc. Am. 42:1185. (Abstract)

Hamilton, E.L., Bachman, R.T., Berger, W.H., Johnson, T.C., and Mayer, L.A., 1982. Acoustic and related properties of calcareous deep-sea sediments. $J$. Sediment. Petrol., 52:733-753.

Johnson, T.C., Hamilton, E.L., and Berger, W.H., 1977. Physical properties of calcareous ooze: control by dissolution at depth. Mar. Geol., 24:259-277.

Kroenke, L.W., Berger, W.H., Janecek, T.R., et al., 1991. Proc. ODP, Init. Repts., 130: College Station, TX (Ocean Drilling Program).

\section{A}

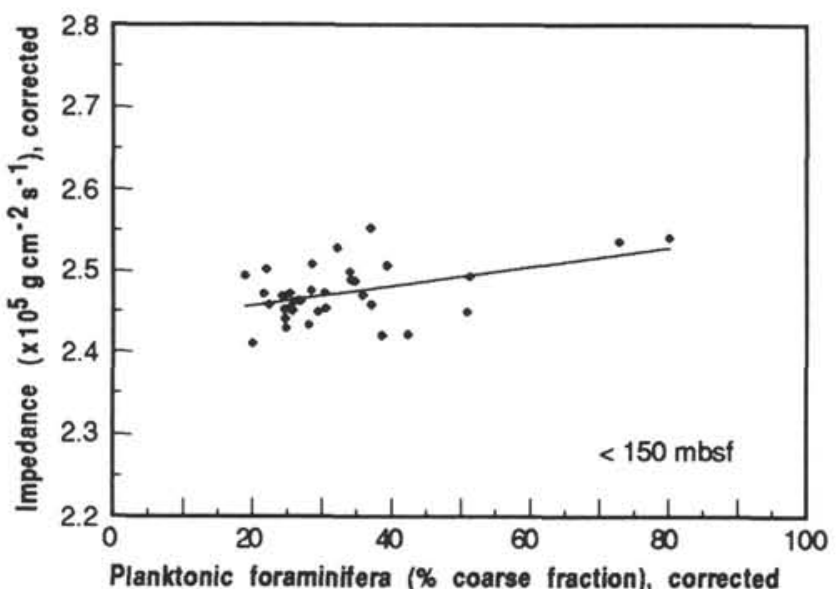

C

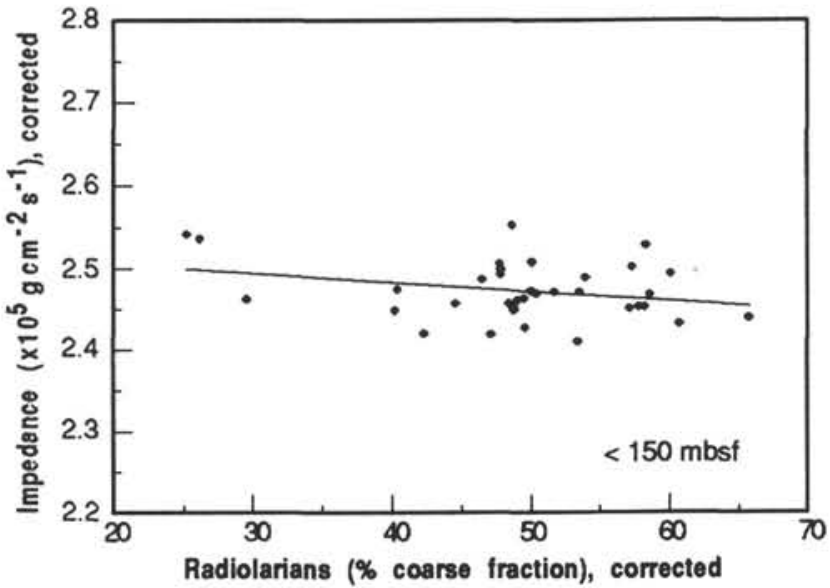

Mayer, L.A., 1979. Deep sea carbonates: acoustic, physical, and stratigraphic properties. J. Sediment. Petrol., 49:819-836.

Mayer, L.A., Courtney, R.C., and Moran, K., 1987. Ultrasonic measurements of marine sediment properties. Proc. Oceanogr., 87:1-139.

Noorany, I., 1984. Phase relations in marine soils. J. Geotech. Eng., 110:539-543.

Schreiber, B.C., 1968. Sound velocity in deep-sea sediments. J. Geophys. Res., 73:1259-1268.

Date of initial receipt: 2 December 1991

Date of acceptance: 4 August 1992

Ms 130B-045

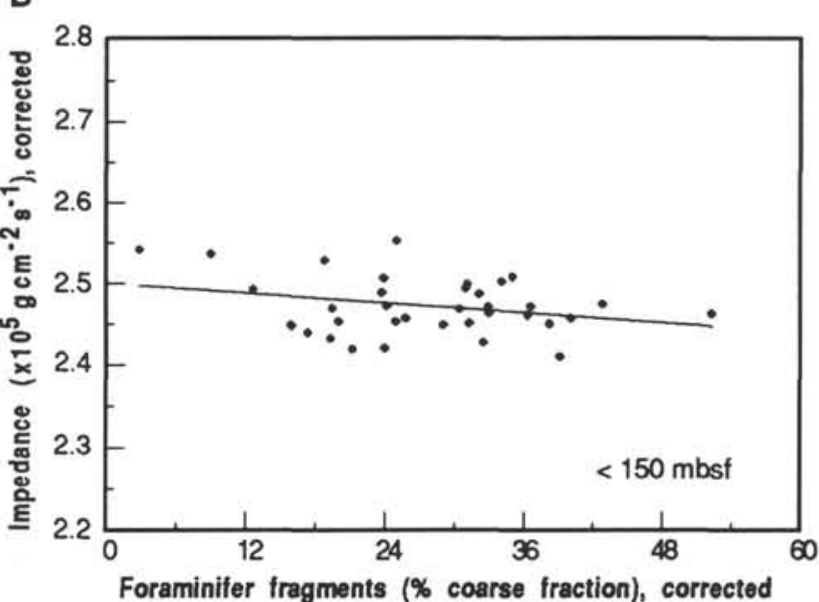

Figure 12. A. Impedance vs. percentage of planktonic foraminifers. The least-squares fit to the data has the equation: Impedance $=2.43+0.0012(\%$ foraminifers); $R=0.46$. B. Impedance vs. percentage of foraminifer fragments. The least-squares fit to the data has the equation: Impedance $=2.50-0.001$ (\% foraminifer fragments); $R=0.30$. C. Impedance vs. percentage of radiolarians. The least-squares fit to the data has the equation: Impedance $=2.53-$ 0.0011 (\% radiolarians); $R=0.29$. 


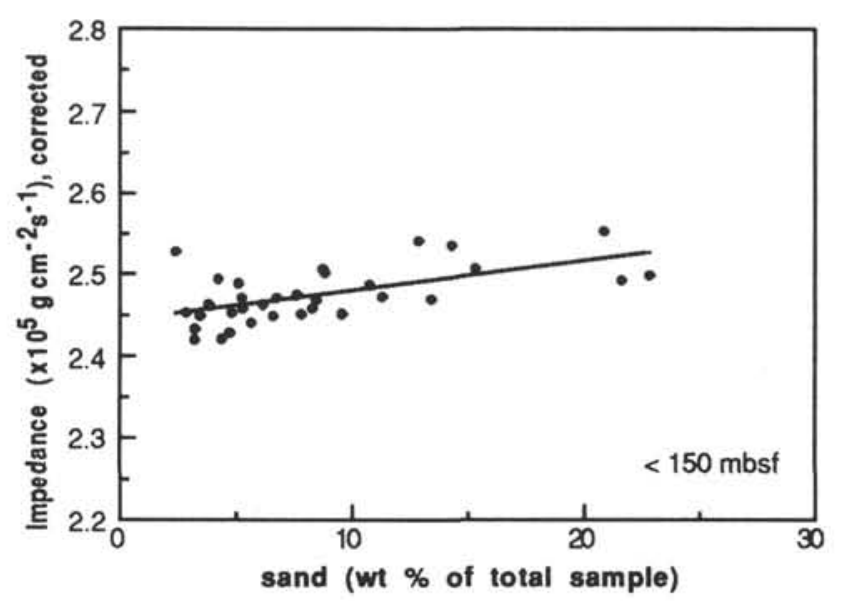

Figure 13. Impedance vs. percentage of coarse fraction. The least-squares fit to the data has the equation: Impedance $=2.44+0.0036$ (\% sand); $R=0.59$.
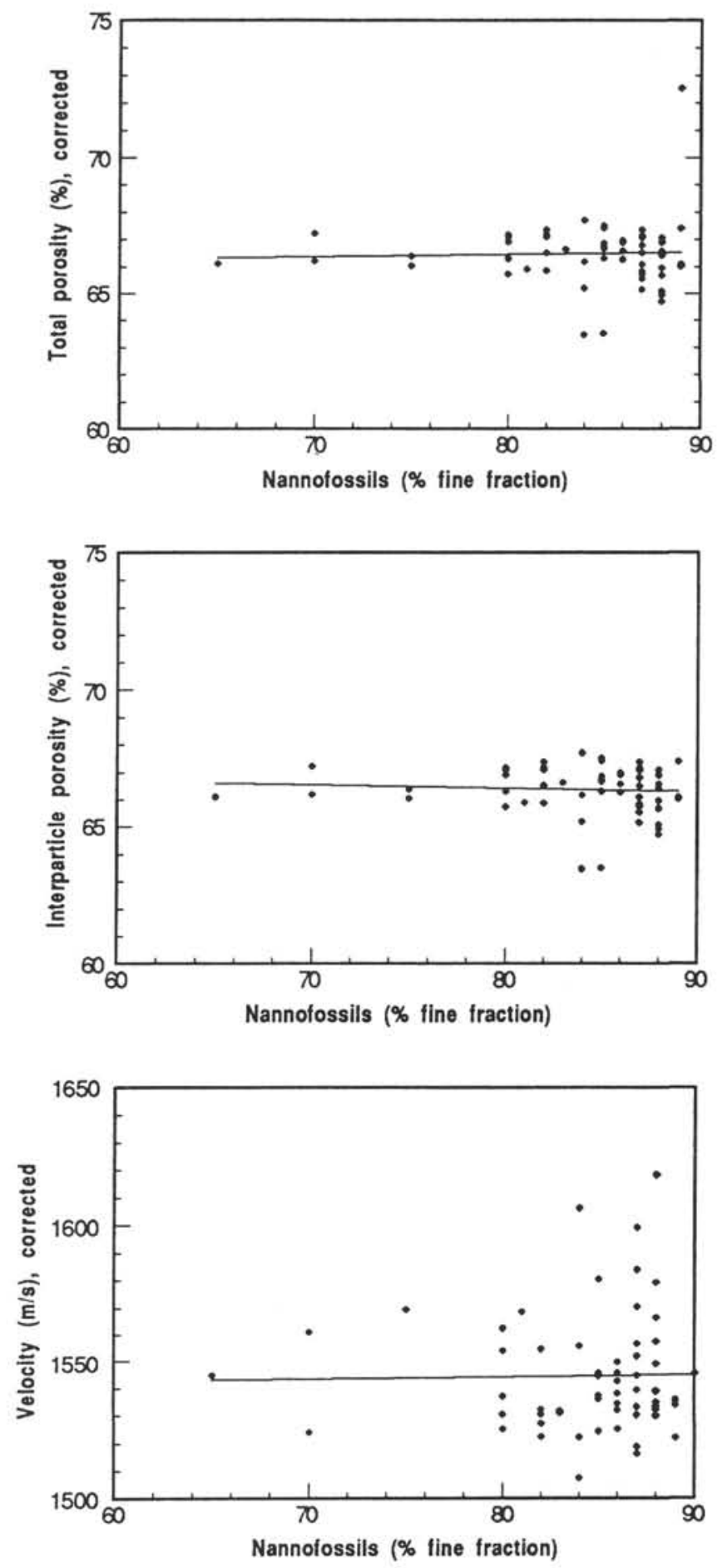

Figure 14. Total porosity, interparticle porosity, and velocity vs. percentage of nannofossils. 